\title{
PELATIHAN PENULISAN CV BERBAHASA INGGRIS UNTUK SEKOLAH BAHASA ONLINE
}

\author{
Natalia Faradheta Putri ${ }^{1}$, Santi Delliana ${ }^{2}$ \\ ${ }^{1,2}$ Program Studi Ilmu Komunikasi, Fakultas Bisnis dan Komunikasi, Institut Teknologi dan Bisnis Kalbis \\ natalia.putri@kalbis.ac.id
}

\begin{abstract}
Abstrak Menulis CV dalam bahasa Inggris mungkin merupakan hal yang mudah dilakukan jika kita memiliki kemampuan berkomunikasi dalam bahasa Inggris. Apalagi di era sekarang ini, mengakses contoh CV dari internet merupakan hal yang sangat mudah. Namun, pekerjaan sederhana ini mungkin rumit bagi sebagian orang karena mereka tidak tahu harus mulai dari mana dalam proses penulisan CV ini. Oleh karena itu, Tim Pengabdian Masyarakat dari Jurusan Ilmu Komunikasi Kalbis Institute mencoba mengisi celah tersebut dengan melakukan pengabdian masyarakat dalam penulisan CV dengan bekerjasama dengan Sekolah Bahasa Online. Sekolah Bahasa Online adalah salah satu penyelenggara kursus bahasa online di Indonesia. Muridmuridnya berasal dari berbagai daerah di Indonesia dan dunia. Setelah melakukan survei mini terhadap siswa Sekolah Bahasa Online dan pengikut media sosial, kami memutuskan untuk mengadakan pelatihan penulisan CV dalam bahasa Inggris. Selama pelatihan, para peserta belajar bagaimana menulis $\mathrm{CV}$ yang baik dan komponen-komponen $\mathrm{CV}$ yang baik, serta mengintegrasikan kemampuan bahasa mereka ke dalam CV. Pada akhirnya, para peserta diharapkan untuk melengkapi CV dan tim keluar akan memberikan umpan balik pada CV mereka. Dengan demikian, kami berasumsi bahwa mereka akan dapat membuat CV mereka sendiri secara mandiri.
\end{abstract}

Kata kunci: menulis CV, kemampuan berbahasa Inggris, siswa

\section{Pendahuluan}

Seiring dengan perkembangan zaman, kebutuhan akan kemampuan berkomunikasi menggunakan bahasa Inggris kian meningkat. Salah satunya ditandai dengan semakin banyaknya lowongan pekerjaan yang mencantumkan syarat memiliki kemampuan berkomunikasi dalam bahasa Inggris. Selain itu, semakin banyak pula lowongan pekerjaan yang ditulis menggunakan bahasa Inggris sehingga para pelamar diharapkan pula melamar dengan menggunakan bahasa Inggris. Menulis lamaran pekerjaan maupun Curriculum Vitae (CV) dalam bahasa Inggris mungkin bukan hambatan bagi mereka yang sudah memiliki kemampuan berbahasa Inggris yang mumpuni. Ditambah lagi dengan perkembangan teknologi informasi di era ini, tidak sulit mendapatkan resource atau informasi dari berbagai sumber internasional sehingga siapapun bisa menambah ilmu hanya dengan memanfaatkan internet dengan baik (Lister, 2021). Namun, tidak semua orang memiliki kemampuan berbahasa Inggris yang mumpuni dan tidak tahu harus mulai dari mana.

CV merupakan sarana untuk memasarkan (self-branding) kemampuan diri kita kepada perusahaan (McGee, 2014). Dilansir dari Kompas.com (2020), seorang pakar Career Development, Audi Lumbantoruan, menyatakan bahwa CV yang ditulis dalam bahasa Inggris lebih menarik bagi perusahaan karena pelamar dinilai memiliki kemampuan lebih dalam berbahasa Inggris. Selain itu, dengan memiliki kemampuan berbahasa Inggris yang dapat ditunjukkan dalam $\mathrm{CV}$, lebih banyak peluang yang dapat diraih oleh seorang lulusan baik dalam bidang pekerjaan maupun dalam melanjutkan ke jenjang pendidikan yang lebih tinggi. Akan tetapi, CV tidak disarankan ditulis secara panjang dan bertele-tele dengan memberikan informasi yang terlalu personal. Jackson \& Robbins (2019) menyatakan bahwa informasi yang terlalu personal seperti agama, status perkawinan, informasi terkait pasangan, dan latar belakang kesehatan tidak perlu dijelaskan secara detail dalam CV kecuali perusahaan 
memang meminta informasi tersebut. Informasi personal berupa nama, gelar, alamat, nomor telepon, dan alamat e-mail saja sudah cukup tanpa menyertakan informasi detail lain. Hal ini banyak tidak diketahui oleh pembuat $\mathrm{CV}$ sehingga $\mathrm{CV}$ yang mereka tulis cenderung panjang dan mengandung informasi yang terlalu banyak.

Sebagai lembaga penyelenggara kursus bahasa, Sekolah Bahasa Online melihat tingginya permintaan untuk menyelenggarakan pelatihan penulisan $\mathrm{CV}$ berbahasa Inggris bagi generasi muda melalui survei berupa polling yang dilakukan pada akun Instagram mereka. Setelah melihat kebutuhan ini, Sekolah Bahasa Online mengusulkan program pelatihan bagi generasi muda (mahasiswa dan calon mahasiswa) untuk memulai membangun CV mereka dan memanfaatkan bahasa Inggris sebagai penambah nilai plus dalam CV mereka. Sekolah Bahasa Online menggandeng Program Studi Ilmu Komunikasi Kalbis Institute untuk melaksanakan program pelatihan penulisan CV bagi generasi muda. Program pelatihan ini diusulkan sebagai bentuk Pengabdian Kepada Masyarakat yang merupakan salah satu wujud Tri Dharma Perguruan Tinggi. Harapannya, program pelatihan ini dapat memberikan pandangan kepada para generasi muda tentang kemampuan dan keterampilan apa saja yang perlu dipersiapkan secara matang sebelum melamar pekerjaan maupun beasiswa. Di samping itu, pelatihan ini diharapkan dapat memberikan pandangan mengenai pentingnya bahasa Inggris dalam dunia kerja dan bagaimana kemampuan bahasa Inggris dapat meningkatkan daya tarik CV. Materi yang akan disampaikan pada program pelatihan ini meliputi bagaimana membangun $\mathrm{CV}$ yang baik, menggunakan bahasa Inggris dalam penulisan CV, bagaimana bahasa Inggris dapat membuat CV menjadi lebih menarik, dan bagaimana cara membuktikan kemampuan berbahasa Inggris secara menarik di CV.

Tujuan dari pelatihan penulisan CV adalah karena CV merupakan persyaratan yang sangat penting dalam proses pencarian kerja maupun beasiswa (Januchowski-Hartley, et al., 2019). Akan tetapi, materi mengenai penulisan CV terlebih dalam bahasa Inggris jarang diajarkan di sekolah maupun perguruan tinggi. Menurut Risavy (2017), tidak banyak sumber referensi akademik yang dapat digunakan sebagai acuan dalam penulisan CV berbahasa Inggris dan sumber yang ada biasanya telah ketinggalan zaman. Hal ini mungkin menjadi alasan mengapa penulisan CV jarang dimasukkan ke dalam kurikulum baik di sekolah menengah maupun tingkat perguruan tinggi. Meskipun sumber referensi tentang penulisan $\mathrm{CV}$ banyak ditemukan di situs pencarian dunia maya, informasi tersebut dirasa masih kurang tepat jika digunakan sebagai bahan belajar di dalam kelas (Campbell, 2020). Oleh sebab itu, pelatihan ini diberikan kepada para mahasiswa dan calon mahasiswa sehingga peserta dapat mempersiapkan diri sebaik mungkin. Dengan demikian, peserta dapat menerapkan informasi yang didapatkan dai pelatihan ini ke dalam proses penulisan $\mathrm{CV}$ yang baik dan mempersiapkan kemampuan serta keterampilan yang diperlukan.

\section{Metode}

Metode pelaksanaan kegiatan pelatihan penulisan CV dilaksanakan dalam bentuk pelatihan dan pendampingan. Di tengah pandemi COVID-19 seperti saat ini, metode pelaksanaan kegiatan PKM yang paling memungkinkan adalah dengan memanfaatkan teknologi video conference. Aplikasi Zoom digunakan dalam setiap sesi kegiatan. Kegiatan ini dibagi menjadi dua bagian:

1. Pelatihan

Bagian pertama merupakan bagian pelatihan di mana para peserta diberikan materi mengenai penulisan $\mathrm{CV}$ yang baik dan benar serta cara mengintegrasikan kemampuan berbahasa Inggris dalam CV mereka.

2. Pendampingan 
Bagian kedua merupakan pendampingan di mana para peserta diminta untuk mempraktikkan secara langsung penulisan $\mathrm{CV}$ yang telah mereka pelajari sebelumnya. Tim PKM Program Studi Ilmu Komunikasi Kalbis Institute juga secara memberikan masukan dari hasil tulisan peserta.

\section{Waktu Pelaksanaan}

Kegiatan ini dilaksanakan pada hari Sabtu, 21 Mei 2021 pada pukul 19.00 WIB hingga selesai. Jumlah peserta yang hadir dalam kegiatan ini berjumlah 21 orang termasuk TIM PKM Ilmu Komunikasi Kalbis Institute dan Sekolah Bahasa Online. Kegiatan pertama yang dilakukan adalah pemamparan materi oleh Tim PKM yang dilanjutkan dengan sesi tanyajawab dan pendampingan penulisan $\mathrm{CV}$.

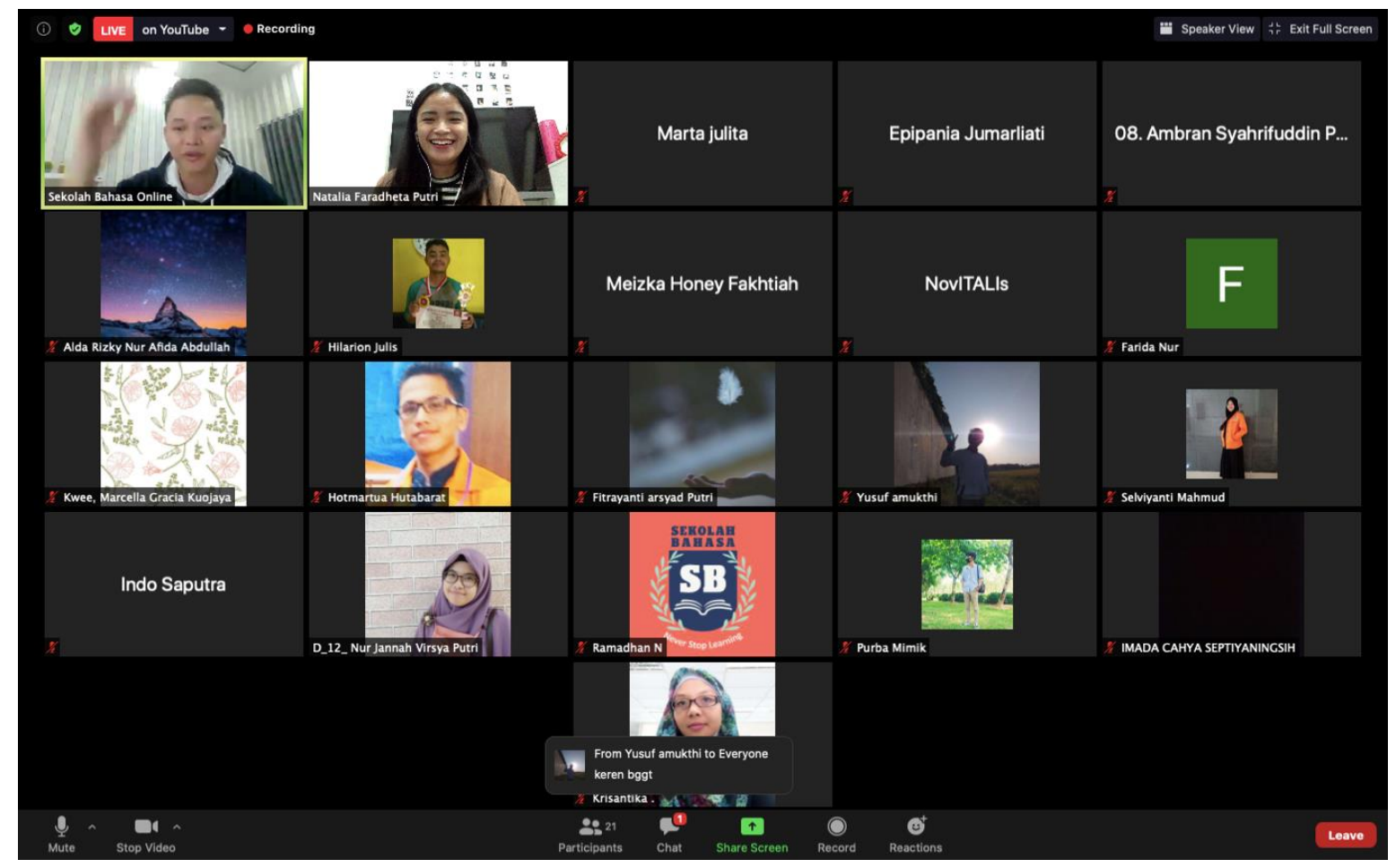

Gambar 1. Pelaksanaan Pelatihan dan Pendampingan

(sumber: pribadi)

\section{Profil Sekolah Bahasa Online}

Sekolah Bahasa Online merupakan lembaga kursus bahasa asing yang menyediakan berbagai kelas bahasa asing online berbayar serta webinar gratis bagi peserta yang tertarik mengikuti berbagai jenis pelatihan. Saat ini, Sekolah Bahasa Online hanya menyediakan program secara daring. Lembaga kursus ini beralamat di Kendaldoyong RT 11 RW 03, Kecamatan Petarukan, Kabupaten Pemalang.

Saat ini Sekolah Bahasa Online memiliki akun Instagram sebagai sarana promosi kepada calon siswa serta situs Sekolah Bahasa Online (www.sekolahbahasaonline.com) yang dapat diakses oleh calon siswa. Situs Sekolah Bahasa Online hanya mencantumkan program dan format kelas serta tutor yang mengajar, sedangkan informasi mengenai kegiatan webinar gratis hanya dipromosikan melalui akun Instagram baik berupa Instagram Story maupun Instagram Post. 
Para siswa dan pengikut akun sosial media Sekolah Bahasa Online merupakan para siswa dan mahasiswa yang memiliki ketertarikan dalam belajar bahasa Inggris. Selain merupakan siswa kelas, banyak diantara pengikut akun sosial media sekolah bahasa yang menantikan kegiatan webinar maupun live Instagram di akun Sekolah Bahasa Online. Sekolah Bahasa Online juga kerap kali melakukan survey atau polling di akun Instagram mereka untuk mengetahui kebutuhan para pengikutnya. Berdasarkan hasil survey singkat, ditemukan bahwa banya diantara pengikut dan siswa Sekolah Bahasa Online yang memiliki kendala dalam mendaftar beasiswa dan melamar pekerjaan. Berdasarkan kendala tersebut, didapati bahwa kendala tersebut berakar pada kurang terampilnya generasi muda dalam menuliskan CV. Oleh sebab itu, pelatihan penulisan CV dalam bahasa Inggris diperlukan untuk membantu menyelesaikan permasalahan yang dihadapi oleh mitra.

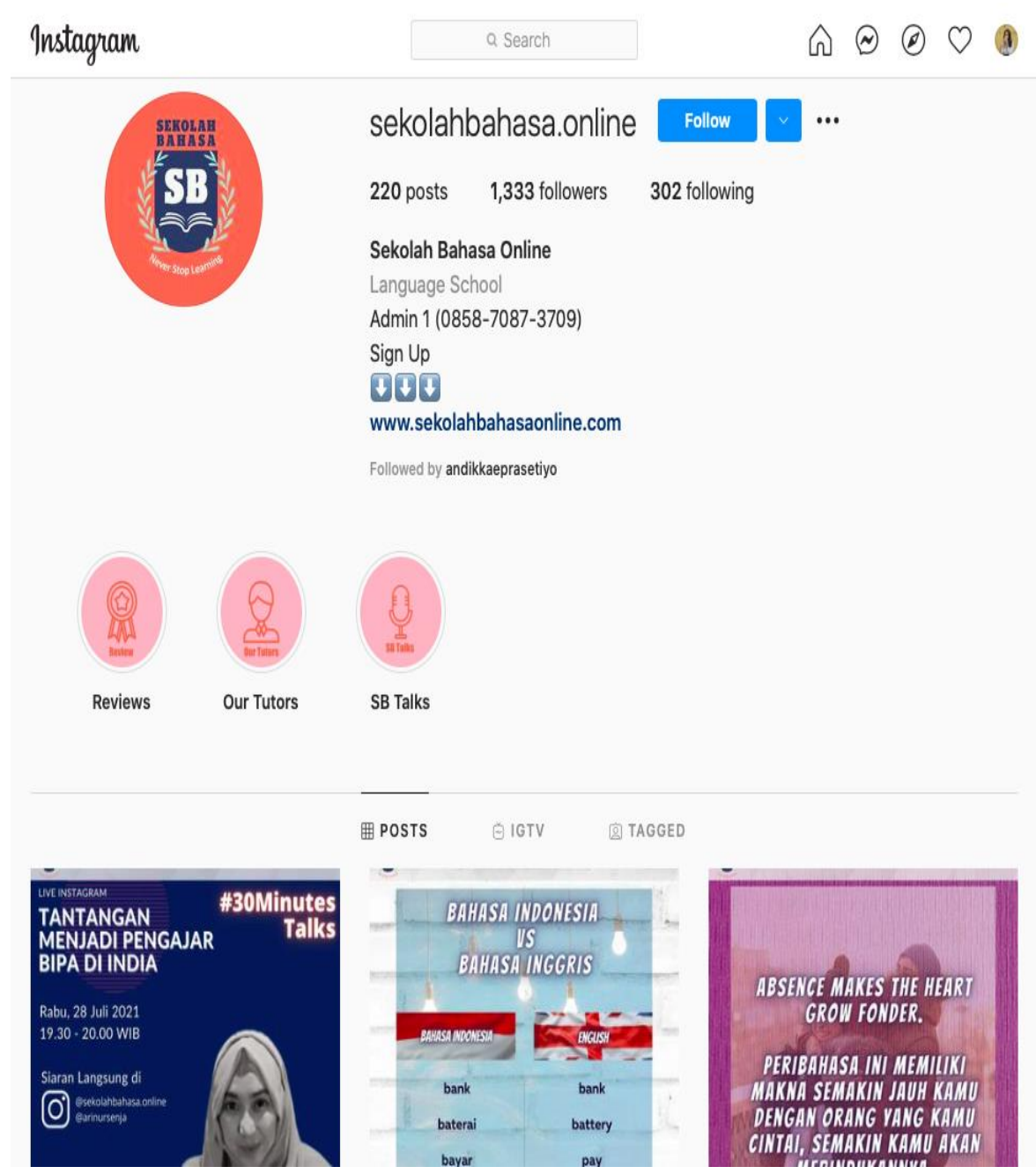

Gambar 2. Halaman Akun Instagram Sekolah Bahasa Online (sumber: https://www.instagram.com/sekolahbahasa.online/) 


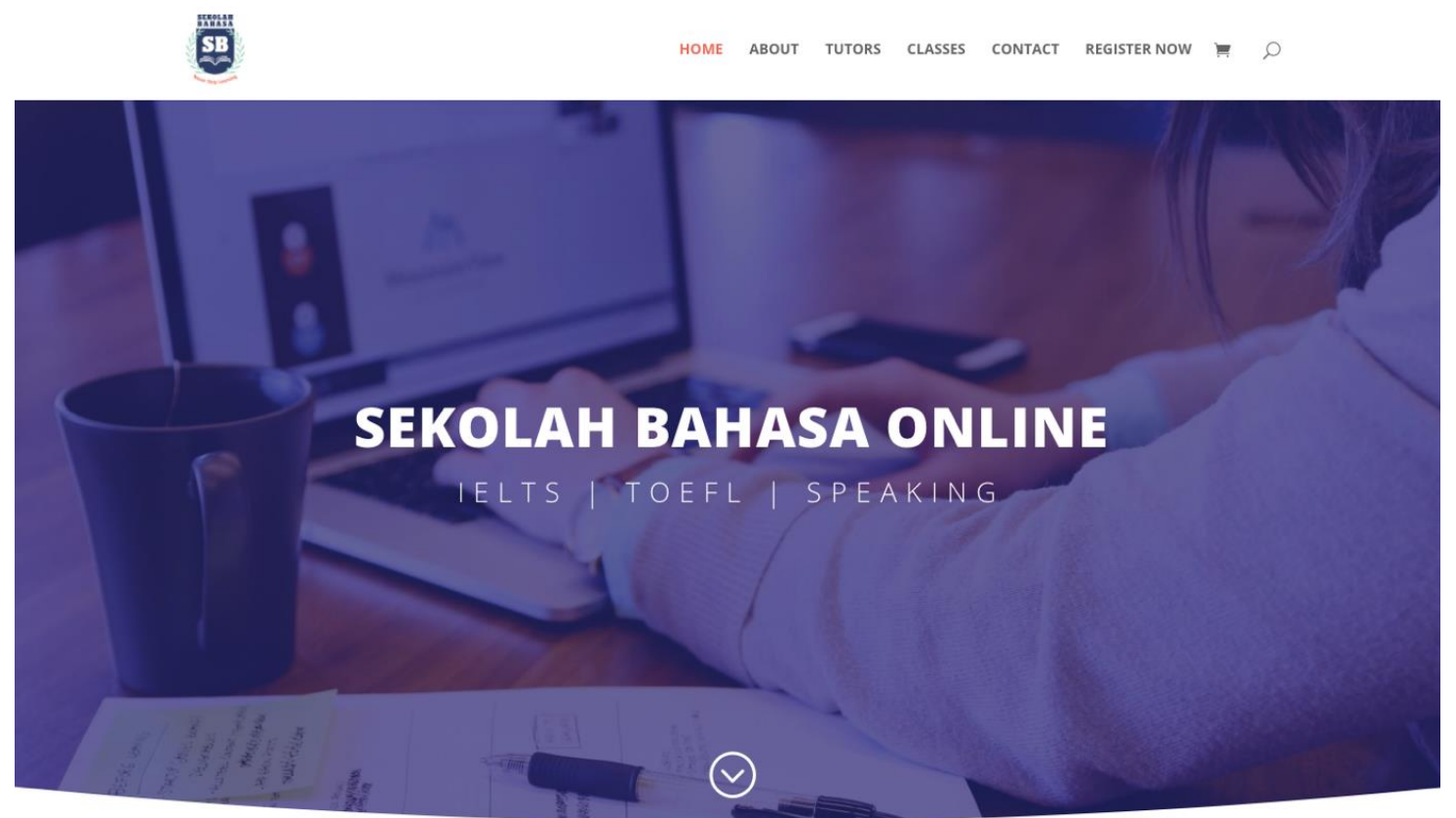

Gambar 3. Halaman Situs Sekolah Bahasa Online

(sumber: https://sekolahbahasaonline.com)

\section{Hasil dan Pembahasan}

Kegiatan pelatihan penulisan CV dilaksanakan secara daring menggunakan aplikasi Zoom. Aplikasi Zoom digunakan karena sebagian besar peserta sudah familiar dengan aplikasi tersebut dan peserta dapat berinteraksi secara langsung dengan pemateri dengan mengajukan pertanyaan maupun berdiskusi. Para peserta sebelumnya sudah diminta untuk mengumpulkan CV mereka masing-masing untuk dicek oleh pemateri. Pada hari pelaksanaan pelatihan, sebelum materi diberikan, pemateri mengadakan diskusi tanya jawab dengan para peserta untuk mengetahui sejauh mana pengetahuan mereka tentang pentingya menulis CV yang baik dan pentingnya menggunakan bahasa Inggris dalam penulisan CV. Setelah sesi tanya jawab dilakukan, pemateri memaparkan materi kepada peserta.

Materi yang diberikan merupakan materi seputar pentingnya menguasai bahasa Inggris, kosa kata bahasa Inggris yang lazim digunakan dalam CV, cara mencari informasi seputar $\mathrm{CV}$ dan contoh $\mathrm{CV}$ yang baik di internet, informasi yang wajib (dan tidak) untuk dimasukkan ke dalam CV, penulisan CV yang menarik, dan cara memanfaatkan kemampuan berbahasa Inggris ke dalam skill yang dimiliki dan/atau posisi yang akan dilamar. Selanjutnya, setelah pemaparan materi dan pemberian contoh penulisan CV yang baik dan benar, peserta diminta untuk menuliskan CV mereka masing-masing. Beberapa peserta diberikan kesempatan untuk mempresentasikan hasil CV mereka kepada pemateri untuk diberi masukan. Peserta juga diberi kesepatan untuk bertanya dan berdiskusi dengan pemateri. Diakhir acara, seluruh peserta diminta untuk mengumpulkan $\mathrm{CV}$ yang telah mereka susun untuk selanjutnya diberikan masukan oleh pemateri.

Jika ditelisik kembali, CV yang dikumpulkan oleh peserta sebelum kegiatan pelatihan dilaksanakan mayoritas ditulis dengan menggunakan bahasa Indonesia, hanya sebagian kecil yang mengumpulkan dengan bahasa Inggris. Hampir seluruh peserta pelatihan menuliskan CV yang cukup panjang dengan memberikan informasi yang tidak efektif dan cukup berteletele. Hanya beberapa peserta yang menuliskan CV dengan singkat, padat, dan jelas. Pada saat sesi taya-jawab dilangsungkan, diketahui bahwa sebagian besar peserta menganggap bahwa 
semakin panjang CV ditulis, semakin menarik pula profil mereka di mata perusahaan atau provider beasiswa yang dituju.

Saat mereview CV yang ditulis oleh peserta setelah mengikuti pelatihan, kami menemukan bahwa CV yang ditulis oleh peserta jauh lebih baik. Tidak lagi ditemukan CV dengan lebih dari 3 halaman, hampir seluruh CV yang dihasilkan ditulis maksimal 2 halaman dengan bahasa yang efektif dan menggunakan bahasa Inggris yang tepat. Dari peningkatan kualitas CV yang ditulis oleh peserta, dapat dikatakan bahwa kegiatan pelatihan ini berjalan dengan baik. Hal ini juga terlihat dari antusiasme peserta dan keikutsertaan aktif para peserta dalam setiap sesi baik dalam bentuk tanya jawab maupun diskusi.

Harapannya, para peserta bisa terus mengaplikasikan pembekalan yang diberikan dan mempersiapkan diri untuk membangun $\mathrm{CV}$ yang baik serta dapat mendemonstrasikan kemampuan serta keterampilan secara efektif yang tertuang dalam CV mereka. Kedepannya, kerja sama Program Studi Ilmu Komunikasi Kalbis Institute dengan mitra PKM dapat berjalan sehingga semakin banyak pembekalan dan materi yang dapat diberikan sesuai dengan kebutuhan para peserta. Selain dari melaksanakan kegiatan PKM dengan tema penulisan CV dalam bahasa Inggris, ke depannya mitra berharap akan ada pelatihan presentation skill dalam bahasa Inggris yang menarik. Akan tetapi, kegiatan secara tatap muka mungkin belum dapat dilakukan mengingat lokasi mitra yang tersebar di berbagai kota di Indonesia.

\section{Kesimpulan}

Setelah kegiatan pelatihan dilaksanakan, keterampilan para peserta dalam menuliskan CV dapat dikatakan mengalami peningkatan yang cukup baik. Peserta mampu menuliskan $\mathrm{CV}$ dalam bahasa Inggris dengan menggunakan kosa kata yang tepat, bahasa yang ringkas dan efektif, dan mampu mengintegrasikan dan/atau mempresentasikan kemampuan berbahasa Inggris mereka dalam skill lain yang dimiliki (atau yang dibutuhkan pada posisi yang dilamar). Secara keseluruhan, kegiatan ini dinilai sangat bermanfaat dan dapat membantu peserta dalam memahami penulisan $\mathrm{CV}$ yang menarik dalam bahasa Inggris. Hal ini dapat dilihat dari animo mitra dalam berdiskusi, bertanya, dan ikut berlatih selama kegiatan pelatihan berlangsung. Harapannya, peserta tidak hanya berhenti di sini namun secara mandiri dapat mengaplikasikan pengetahuan yang diberikan ke dalam $\mathrm{CV}$ yang mereka tulis.

\section{Ucapan Terima Kasih}

Kami mengucapkan terima kasih kepada Kalbis Institute dan Yayasan Pendidikan Kalbe yang telah memberi dukungan penuh atas terlaksananya kegiatan pengabdian kepada masyarakat ini. Disamping itu, kami juga berterima kasih kepada Sekolah Bahasa Online yang telah memberikan kepercayaan kepada kami untuk memberikan pelatihan.

\section{Daftar Pustaka}

Campbell, E. V. (2020). Resume Writing in English: Comparing the Beliefs and Practices of Mexican University Students with Conventions in English-Speaking Countries. MEXTESOL Journal, 44(4).

Lister. (2021, Maret 19). Seberapa Penting Penguasaan Bahasa Inggris di Dunia Kerja ? Retrieved Juli 2021, from https://lister.co.id/seberapa-penting-penguasaan-bahasainggris-di-dunia-kerja/ 
Kompas.com. (2020, Maret 02). Lebih Baik CV Bahasa Inggris atau Indonesia? Ini Kata Pakar HRD. Retrieved Juli 2021, from https://money.kompas.com/read/2020/03/02/073853526/lebih-baik-cv-bahasa-inggrisatau-indonesia-ini-kata-pakar-hrd?page $=$ all

McGee, P. (2014). How to Write a CV that Really Works: A Concise, Clear and Comprehensive Guide to Writing an Effective CV. London, UK: Constable \& Robinson Ltd.

Jackson, T. L., \& Robbins, S. A. (2019). CV Writing Workshop (No. LA-UR-19-26689). Retrieved Juli 2021, from https://permalink.lanl.gov/object/tr?what=info:lanlrepo/lareport/LA-UR-19-26689

Januchowski-Hartley, S. R., Mantel, S. K., Barber-James, H. M., Celi, J., Olden, J. D., Piccolo, J. J., \& Hermoso, V. (2019). Perceptions of a curriculum vitae clinic for conservation science students. Conservation Science and Practice, 1(16).

Risavy, S. D. (2017). The resume research literature: where have we been and where should we go next? Journal of Educational and Developmental Psychology, 7(1), 169-187. 